University of Nebraska - Lincoln

DigitalCommons@University of Nebraska - Lincoln

Faculty Publications from the Harold W. Manter Laboratory of Parasitology

$4-1-1973$

\title{
Seasonal Carbon Dioxide and Oxygen Concentrations in the Dens of Hibernating Mammals (Sciuridae)
}

D. D. Williams

Arctic Health Research Center

Robert L. Rausch

Arctic Health Research Center, rausch@u.washington.edu

Follow this and additional works at: https://digitalcommons.unl.edu/parasitologyfacpubs

Part of the Parasitology Commons

Williams, D. D. and Rausch, Robert L., "Seasonal Carbon Dioxide and Oxygen Concentrations in the Dens of Hibernating Mammals (Sciuridae)" (1973). Faculty Publications from the Harold W. Manter Laboratory of Parasitology. 541.

https://digitalcommons.unl.edu/parasitologyfacpubs/541

This Article is brought to you for free and open access by the Parasitology, Harold W. Manter Laboratory of at DigitalCommons@University of Nebraska - Lincoln. It has been accepted for inclusion in Faculty Publications from the Harold W. Manter Laboratory of Parasitology by an authorized administrator of DigitalCommons@University of Nebraska - Lincoln. 


\title{
SEASONAL CARBON DIOXIDE AND OXYGEN CONCENTRATIONS IN THE DENS OF HIBERNATING MAMMALS (SCIURIDAE)
}

\author{
D. D. WILLIAMS and R. L. RAUSCH \\ Arctic Health Research Center, Bureau of Community Environmental Management, \\ Health Services and Mental Health Administration, Department of Health, \\ Education and Welfare, Fairbanks, Alaska 99701
}

(Received 3 fuly 1972)

\begin{abstract}
Weekly temperature and respiratory gas concentrations were measured in the artificial dens of Citellus parryi ablusus and Marmota broweri for 1 year.

2. Nest boxes attained temperatures as low as -12 and $-25^{\circ} \mathrm{C}$ for the ground squirrels and marmots, respectively.

3. Carbon dioxide levels as high as $13 \cdot 5$ per cent and oxygen levels as low as 4 per cent were measured in the marmots' nest box during the winter.
\end{abstract}

\section{INTRODUCTION}

To WHAT extent can the composition of air be altered in the passageways and burrows of hibernating mammals and still support life ? Gesner recognized the possible existence of anoxia in the sealed burrows of hibernating species as early as 1551 , but actual measurements of the respiratory gases in natural or artificial mammalian burrows have been reported by only a few investigators. Air in the burrow of the pocket gopher Geomys bursarius was studied by Kennerly (1964) and $\mathrm{McNab}$ (1966) and in that of the European rabbit Oryctolagus cuniculus (Linnaeus) by Hayward (1966). Studier \& Baca (1968) and Studier \& Procter (1971) studied five species of rodents which included hibernators: Citellus tridecemlineatus, Eutamias quadrivittatus, Neotoma albigula, Dipodomys ordii and Rattus norvegicus.

In arctic and sub-arctic regions, hibernating mammals may be confined to their dens for up to 8 months. The combination of sealed or partially sealed dens and periodic arousals or intensive activity at normal body temperature during this confinement could result in large changes in the concentrations of $\mathrm{O}_{2}$ and $\mathrm{CO}_{2}$. This paper reports seasonal changes in respiratory gases in artificial dens of two species of hibernators indigenous to central and northern Alaska: Citellus parryi ablusus (Osgood) and Marmota broweri Hall and Gilmore.

\section{MATERIALS AND METHODS}

The ground squirrels were captured 150 miles south of Fairbanks in the Alaska Range. The marmots came from a colony descended from a pair of adults captured in the spring of 1964 at Chandler Lake, in the central Brooks Range, arctic Alaska. 
Both groups were housed in artificial dens located in an undisturbed wooded area near Fairbanks, Alaska. The two dens consisted of nest boxes placed at the bottom of enclosed, 6-ft wooden shafts provided with tubes that extended diagonally to ground level within fenced enclosures measuring $20 \times 40 \mathrm{ft}$. The nest boxes were constructed of $\frac{3}{4}$ in. plywood lined with $\frac{1}{4}$ in. cement asbestos board. The dimensions of the dens and nest boxes are given in Figs. 1 and 2. In the marmot dens, all nest boxes were interconnected by openings

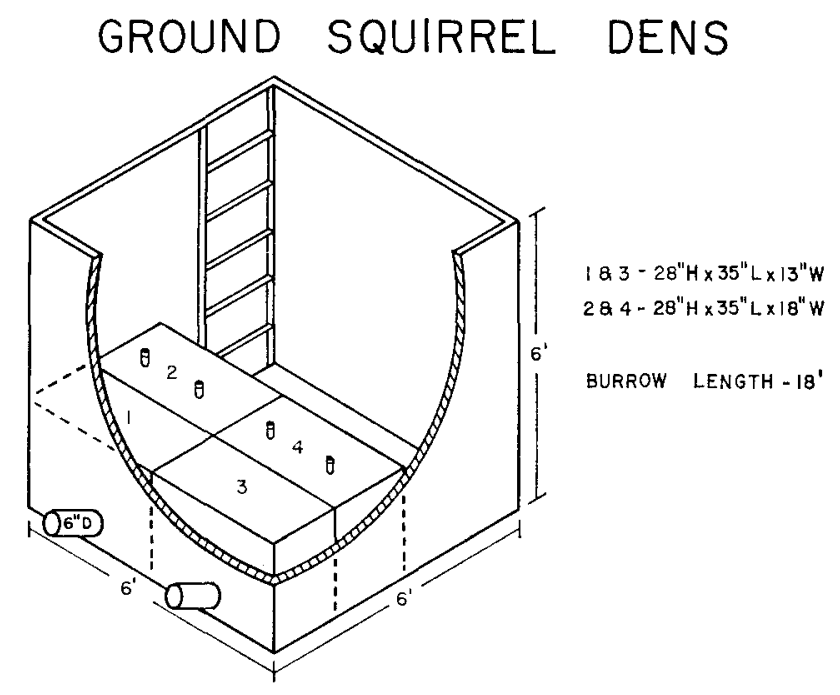

FIG. 1

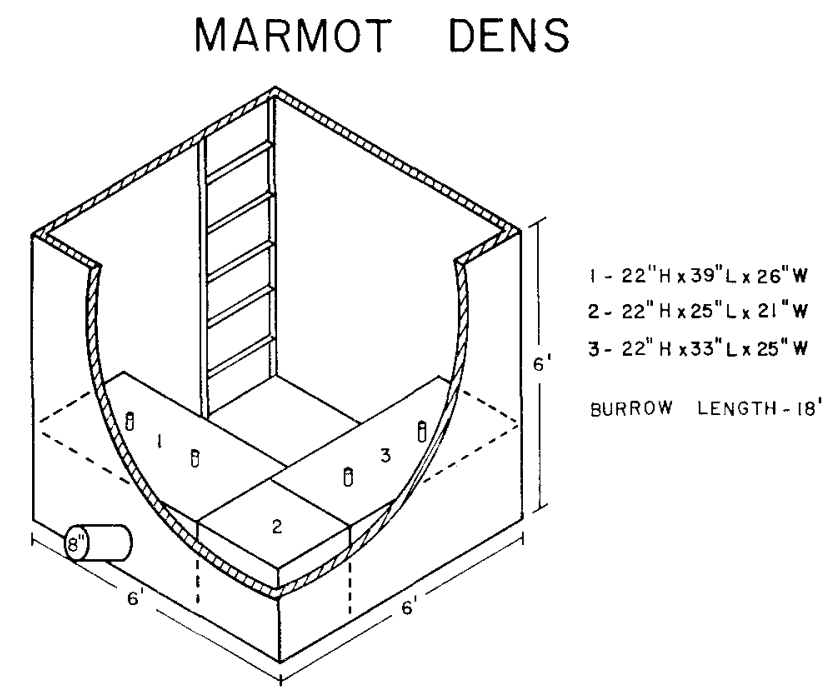

FIG. 2

FIgs. 1 and 2. Construction design and dimensions of artificial dens. 


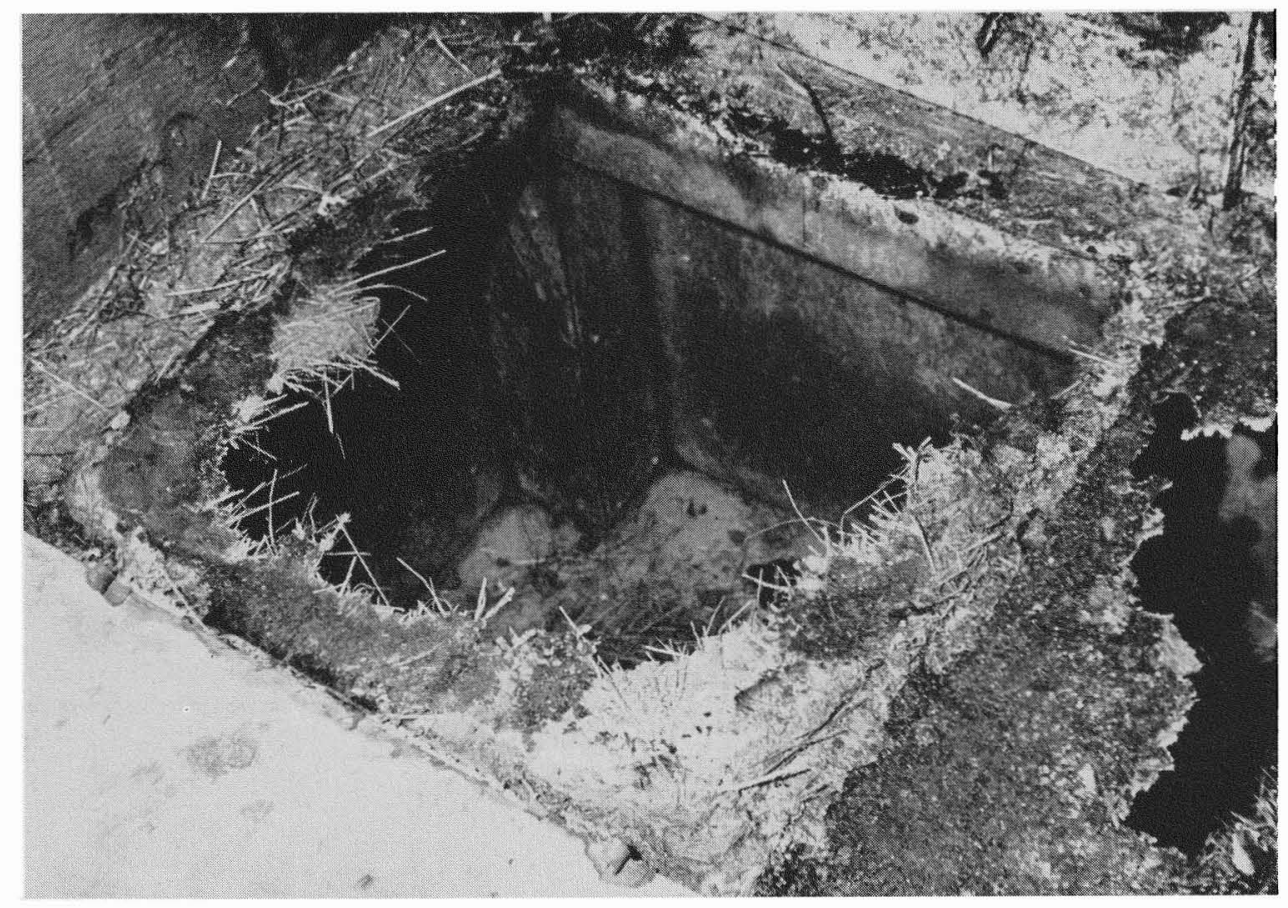

FIG. 3. Interior of marmot nest box with lid raised. Note frozen mixture of feces and hay used to seal crack around the lid of the nest box. 
in the intervening partitions, giving the animals a choice of location of the nest and toilet area. The acceptance of the artificial dens by this species is indicated by the twenty-nine young that have been born in this colony since the spring of 1965 . For the ground squirrels, two separate dens were provided, each consisting of interconnecting nest boxes (designated 1-2 and 3-4, respectively). The tops of the nest boxes for both species were hinged to allow inspection of the nests and facilitate capture of the animals. The animals were provided with hay for nesting material and fed carrots, lettuce and Purina rat chow ad lib. during the summer months.

In preparation for hibernation the marmots modified the nest boxes and burrow as described earlier (Rausch \& Rausch, 1971). The mouth of the burrow at ground level was tightly plugged with a mixture of soil, nesting material and feces. The crack around the hinged lid on the nest boxes was also tightly sealed by the animals with a mixture of feces and nesting material (Fig. 3). Modifications by the ground squirrels consisted only of a small amount of loose nesting material placed in the mouth of the burrow at ground level.

At the beginning of this study eight marmots were housed in the single den; these were three adults and five animals born the previous spring. Marmots of this species are known to hibernate naturally as a family group in a single nest (Rausch $\&$ Rausch, 1971). In contrast, arctic ground squirrels do not naturally share a common burrow; of the six animals placed in the dens (three animals in each den) only four animals appeared in the spring; two apparently were cannibalized.

Thermistors were permanently located within the nest boxes and gas samples were obtained by inserting a surgical rubber tube into the nest box through a stoppered pipe permanently installed in the lid. Gas samples were collected in well lubricated $100-\mathrm{ml}$ glass syringes. The syringes were flushed six to eight times to ensure mixing of the air in the nest box prior to sampling. Atmospheric air samples were also taken as controls. Gas concentrations were estimated with a Scholander $0.5 \mathrm{cc}$ gas analyzer at $26^{\circ} \mathrm{C}$ (Scholander, 1947). Temperatures and gas samples were obtained on the same day each week for the months of January-December 1970. In addition, beginning on 27 December and continuing until 31 March, 1971, daily measurements of gas and temperature were recorded in the marmots' nest box.

\section{Temperature}

\section{RESULTS}

In Fig. 4 ambient and nest box temperatures are plotted for those days when gas samples were obtained. The annual ambient temperature range was $60^{\circ} \mathrm{C}$; that in the squirrels' nest box, $33^{\circ} \mathrm{C}$; and in the marmots' nest box, $36^{\circ} \mathrm{C}$. The lowest temperatures recorded in the nest boxes were $-12^{\circ} \mathrm{C}$ for the squirrels (Fig. 4) and $-25^{\circ} \mathrm{C}$ for the marmots (Fig. 7).

\section{Respiratory gases}

Only a small annual fluctuation in amounts of carbon dioxide and oxygen was observed in the ground squirrel dens. The lowest oxygen level measured was 20 per cent and the highest carbon dioxide level was 1 per cent (Fig. 5).

In the marmot den the annual fluctuation of respiratory gases was much more extreme (Fig. 6). Even during the summer months $\mathrm{CO}_{2}$ values as high as 4 per cent were obtained, with a mean $\mathrm{CO}_{2}$ level of 1.7 per cent during this period. However, the greatest extremes were recorded in the winter after the marmots sealed their nest box. Values of $6 \% \mathrm{CO}_{2}$ and $13 \% \mathrm{O}_{2}$ in the second week of 


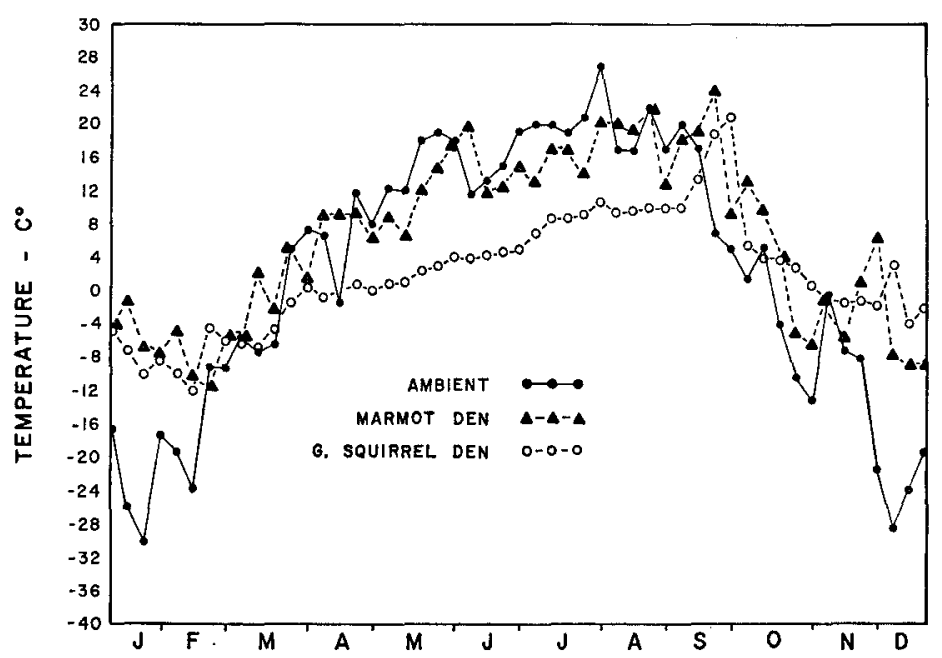

FIG. 4. Plot of weekly ambient and nest box temperature.

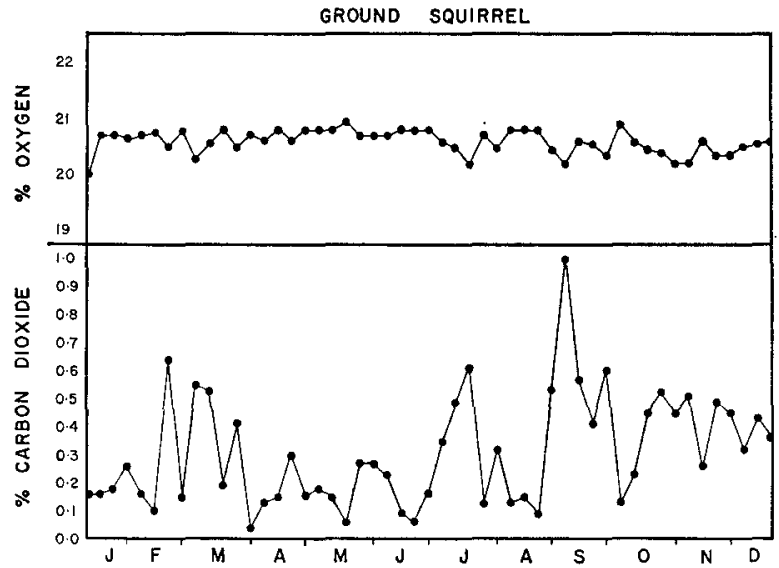

FIG. 5. Plot of weekly $\mathrm{CO}_{2}$ and $\mathrm{O}_{2}$ concentrations from ground squirrels' nest box.

November 1970, prompted us to open the lid of the nest box and inspect the den for possible decaying nesting material. All animals were active at this time and the old nesting material was removed and replaced with fresh hay, even though the nest was dry. The marmots immediately resealed the nest box and values of $9.5 \% \mathrm{CO}_{2}$ and $9 \% \mathrm{O}_{2}$ were recorded the following week. The highest value for $\mathrm{CO}_{2}, 13.5$ per cent, and lowest value for $\mathrm{O}_{2}, 4$ per cent, were recorded on 23 December 1970. Subsequent to this observation we initiated daily sampling in 


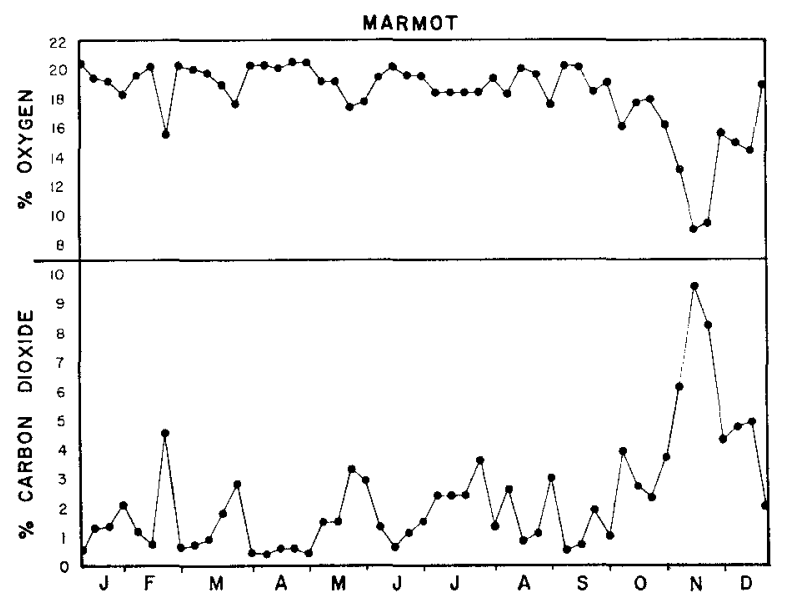

FIG. 6. Plot of weekly $\mathrm{CO}_{2}$ and $\mathrm{O}_{2}$ concentrations from marmots' nest box.

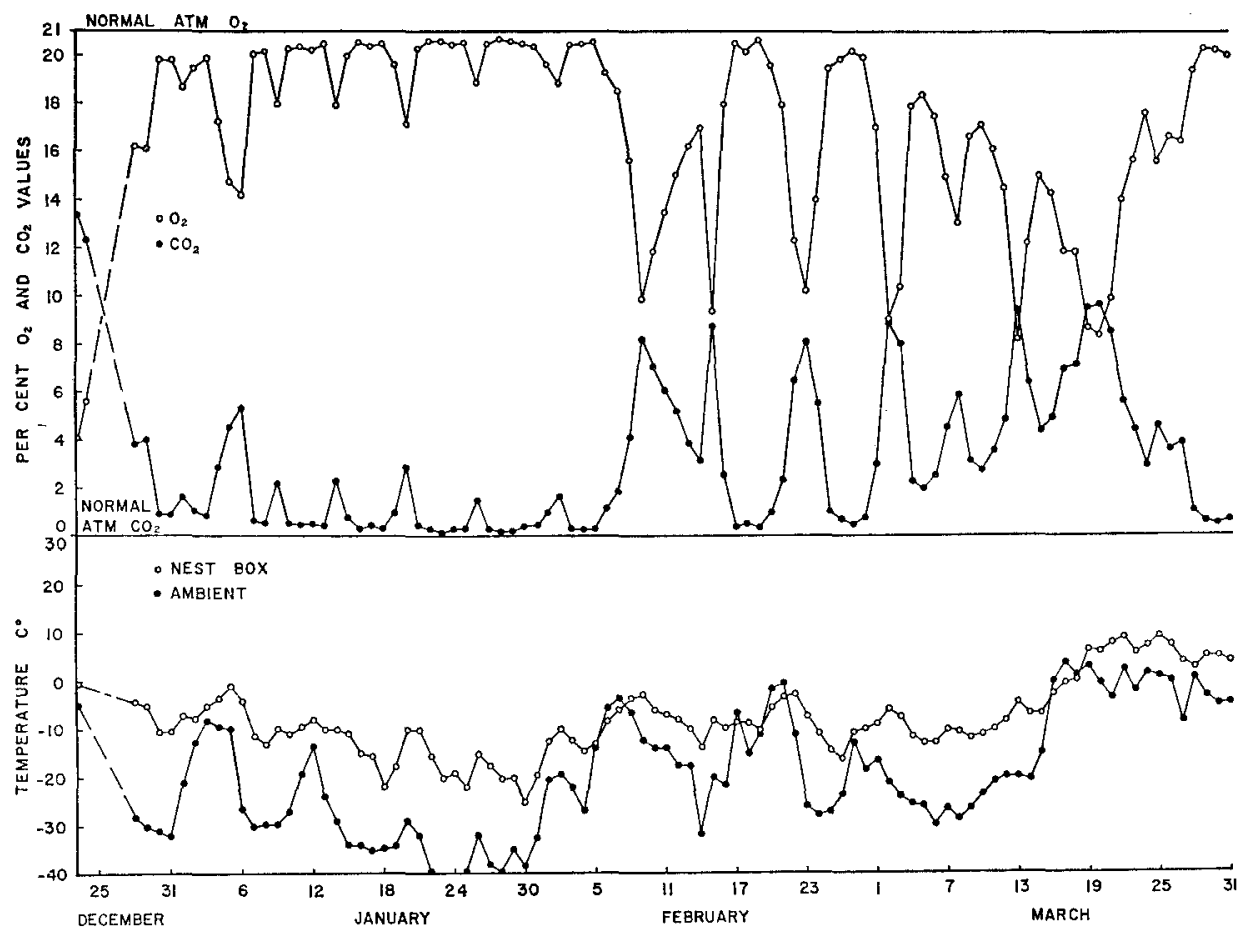

Fig. 7. Daily temperatures, $\mathrm{CO}_{2}$ and $\mathrm{O}_{2}$ concentrations from marmots' nest box. 
order to estimate how long specific gas concentrations were maintained (Fig. 7). The marmots removed the plug from the mouth of their burrow on 21 March 1971.

The more detailed data in Fig. 7 reveal an apparent cycle in the concentrations of $\mathrm{CO}_{2}$ and $\mathrm{O}_{2}$ in the marmots' nest box with a duration (peak to peak) of 5-8 days. During March this cycle remained prominently superimposed on a continually rising level of $\mathrm{CO}_{2}$ and decreasing level of $\mathrm{O}_{2}$ until the animals opened their burrow.

\section{DISCUSSION}

Data in Fig. 4 show nest box temperatures below $0^{\circ} \mathrm{C}$ to be a common occurrence during the winter months for both species. It should be noted, however, that our temperature probes measured only the air temperature within the nest box and not the actual nest temperature which would be expected to be higher.

It is generally assumed that a decrease in nest temperature much below $0^{\circ} \mathrm{C}$ will act as a stimulus for arousal from hibernation, and that animals failing to arouse will die in hibernation (Lyman \& Chatfield, 1956). Mayer (1955) has measured temperatures as low as $-8.8^{\circ} \mathrm{C}$ in the natural burrow of the arctic ground squirrel and therefore our measurement of $-12^{\circ} \mathrm{C}$ in the artificial den of this species is not excessively low.

The daily data from the marmots (Fig. 7) indicate that air temperatures within the den ranged from 0 to $-25^{\circ} \mathrm{C}$ during January 1971 . Even with the protection afforded by the nesting material, these extremely low temperatures would be expected to stimulate either arousal or an increased metabolic level during hibernation. However, the low consumption of oxygen and low production of carbon dioxide during this same period seem to suggest that neither occurred. In fact, this month may have been the period of deepest hibernation as indicated by the small amplitudes of the observed periodic fluctuation in gas concentrations.

Although nest box temperatures of $-25^{\circ} \mathrm{C}$ seem quite low, Folk (1966) observed the hibernation of arctic marmots at ambient temperatures as low as $-48^{\circ} \mathrm{C}$, with a skin temperature of $-5^{\circ} \mathrm{C}$. Until we are able to monitor deep body and/or peripheral temperatures during these periods of low nest box temperatures our data only serve to stimulate speculation on the actual minimal tissue temperatures tolerated by $M$. broweri during hibernation.

The high level of $\mathrm{CO}_{2}$ and low level of $\mathrm{O}_{2}$ tolerated by $M$. broweri evidently reflect an adaptation of this species to denning in permanently frozen ground. During winter, family groups remain together in a single nest. The sealing of the burrow at the surface of the ground prevents access to predators, and probably maintains a higher temperature within the den. Since the animals cannot emerge until the plug has become sufficiently thawed to allow its removal, they may remain within the den for as much as 8 months of the year. Marmots of this species also breed, probably in April, prior to emergence from the den (Rausch \& Rausch, 1971). Consequently, one of the most interesting aspects of the marmots' adaptability to modified respiratory gas concentration is not only their tolerance 
during hibernation, but also their tolerance during periods of presumably normal body temperature and metabolism.

It seems reasonable to interpret the cyclic gas fluctuations as reflecting the arousal of one or more animals from hibernation. The magnitude and amplitude of the cycles during February would seem to indicate a greater synchrony of arousal which culminates in March with a rising baseline representing an increased number of animals becoming active at any given time. In addition, the progressive state of general arousal in early March is confirmed by slowly rising nest box temperatures while ambient temperatures outside the den remain low.

The conditions in the marmots' nest box appear to be comparable to those of the natural den, both in volume and the animals' ability to seal the nest box and burrow entrance. However, the rate of gas diffusion through the walls of our artificial nest may differ from that through the soil of the natural burrow, especially in winter when the ground is frozen.

Hayward (1966) reported levels of $14 \% \mathrm{CO}_{2}$ and $8 \% \mathrm{O}_{2}$ in the burrows of the European rabbit. Although these concentrations resulted in the death of three of the four rabbits housed in the burrow, they were able to tolerate $5 \% \mathrm{CO}_{2}$ and $13 \% \mathrm{O}_{2}$. We are not aware of other reports that mammals can tolerate concentrations of $\mathrm{CO}_{2}$ and $\mathrm{O}_{2}$ of the magnitude and duration observed in this study.

The seasonal fluctuations of $\mathrm{CO}_{2}$ and $\mathrm{O}_{2}$ in the nest boxes of the ground squirrels were not so extreme as were those of the marmots, and were lower than the values reported by Studier et al. $(1968,1971)$ in the artificial and natural burrows of the thirteen-lined ground squirrels. These authors reported extremes of $6.2 \% \mathrm{CO}_{2}$ and $13.7 \% \mathrm{O}_{2}$ in the natural burrow of this species. However, the mean values for their artificial dens were quite similar to our values

The fluctuation in concentration of $\mathrm{O}_{2}$ and $\mathrm{CO}_{2}$ in the natural burrows of $C$. parryi is probably much greater than observed in this study. In addition to the possible higher rate of gas diffusion as mentioned above, the volume of our ground squirrel nest boxes was approximately 100 times that of the natural burrow. Therefore dens with volumes and gas diffusion properties more closely approximating the natural burrow of the ground squirrel must be constructed to obtain realistic values.

The confined atmosphere experienced by $M$. broweri raises several questions of physiological interest. Two of these particularly noteworthy are whether the respiratory gas concentrations produced in the den of this particular species have a causative role in hibernation, and secondly, what alterations in the gas transport system of this species allow the required transport of respiratory gases during periods of low $\mathrm{O}_{2}$ and high $\mathrm{CO}_{2}$.

Chapin \& Edgar (1962) have found that rats, in an atmosphere containing $67 \%$ $\mathrm{O}_{2}$ and $27 \% \mathrm{CO}_{2}$, cool rapidly but do not lose consciousness. This rapid cooling was seen even at $41^{\circ} \mathrm{C}$, and at $12^{\circ} \mathrm{C}$ body temperature dropped to $28^{\circ} \mathrm{C}$ within $45 \mathrm{~min}$. Lowered metabolic rate, lack of shivering and hyperventilation were associated with the decrease in body temperature. In addition it has been shown that at $21 \% \mathrm{O}_{2}$ and at ambient temperatures below the thermoneutral zone, breathing of $\mathrm{CO}_{2}$ at concentrations as low as 4 per cent diminishes heat production 
and reduces body temperature in the rat (Szegvári \& Várnai, 1962; Szegvári et al., 1963).

A similar effect in $M$. broweri, resulting from altered $\mathrm{CO}_{2}$ and $\mathrm{O}_{2}$ levels, would appear to be a useful mechanism aiding periodic entrance into hibernation.

Volkert \& Musacchia (1970) have shown in the hamster Mesocricetus auratus and Musacchia \& Volkert (1971) in the thirteen-lined ground squirrel C. tridecemlineatus, that a $p \mathrm{O}_{2}$ of $30 \mathrm{~mm} \mathrm{Hg}$ is sufficient for 100 per cent saturation of hemoglobin at $6^{\circ} \mathrm{C}$. In addition, in the latter paper, venous $p \mathrm{O}_{2}$ from squirrels hibernating at $6^{\circ} \mathrm{C}$ indicated effective $\mathrm{HbO}_{2}$ dissociation at the tissue level. These data confirm the earlier work of Clausen \& Ersland (1968) in the hibernating hedgehog Erinaceus europaeus. Their data suggest that during hibernation, the tissues may be operating at a $p \mathrm{O}_{2}$ less than $10 \mathrm{~mm} \mathrm{Hg}$.

These authors also studied the Bohr effect on the $\mathrm{HbO}_{2}$ dissociation curve at 5,15 and $38^{\circ} \mathrm{C}$ with a $p \mathrm{CO}_{2}$ of $140 \mathrm{~mm} \mathrm{Hg}$. They found the shift of the curve to the right to be much less pronounced at $5^{\circ} \mathrm{C}$ than at $38^{\circ} \mathrm{C}$ but still quite evident. Because of the high $\mathrm{CO}_{2}$ tension used to obtain a measurable displacement of the curve at low temperatures, it was suggested that the Bohr effect was slight at $5^{\circ} \mathrm{C}$. However, in $M$. broweri it is quite possible that the $p \mathrm{CO}_{2}$ is often $80 \mathrm{~mm} \mathrm{Hg}$ or above. Therefore the high $\mathrm{CO}_{2}$ in the marmots' den and the resultant higher blood $p \mathrm{CO}_{2}$ may significantly shift the curve to the right and facilitate $\mathrm{O}_{2}$ unloading at a higher tissue $p \mathrm{O}_{2}$. These speculations, however, seem applicable only during hibernation and low body temperature-what mechanisms are operating during normal body temperature remains the most stimulating question.

Acknowledgement--The authors would like to thank Mrs. Jill Cameron for her excellent technical assistance.

\section{REFERENCES}

Chapin J. L. \& Edgar J. L. R. (1963) Cooling of rats in carbon dioxide. Am. F. Physiol. 204, 723-726.

Clausen G. \& Ersland A. (1968) The respiratory properties of the blood of the hibernating hedgehog Erinaceus europaeus L. Resp. Physiol. 5, 221-233.

Folk G. E., JR. (1966) Introduction to Environmental Physiology, p. 188. Lea \& Febiger, Philadelphia.

Gesner C. (1551) Cited by Ch. Kayser (1961) The Physiology of Natural Hibernation, p. 56. Pergamon Press, New York.

HAYWARD J. S. (1966) Abnormal concentrations of respiratory gases in rabbit burrows. F. Mammal. 47, 723-724.

KenNerly T. E. (1964) Microenvironment conditions of the pocket gopher. Texas $\mathcal{F}$. Sci. 16, 395-441.

Lyman P. L. \& Chatfield P. O. (1956) Physiology of hibernation in mammals. In The Physiology of Induced Hypothermia (Edited by DrIPPS R. D.). National Academy of Sciences, National Research Council, Pub. 451.

MCNAB B. K. (1966) The metabolism of fossorial rodents: a study of convergence. Ecology 47, 712-733.

MAYER W. V. (1955) The protective value of the burrow system to the hibernating arctic ground squirrel Spermophilus undulatus. Anat. Rec. 122, 437-438. 
Musacchia X. J. \& Volkert W. A. (1971) Blood gases in hibernating and active ground squirrels: $\mathrm{HbO}_{2}$ affinity at 6 and $38^{\circ} \mathrm{C}$. Am. F. Physiol. 221, 128-130.

Rausch R. L. \& Rausch V. R. (1971) The somatic chromosomes of some North American marmots (Sciuridae) with remarks on the relationships of Marmota broweri Hall and Gilmore. Mammalia 35, 85-101.

SCHOLANDER P. F. (1947) Analyzer for accurate estimation of respiratory gases in one-half cubic centimeter samples. F. biol. Chem. 167, 235-250.

StUdier E. H. \& BACA T. P. (1968) Atmospheric conditions in artificial rodent burrows. Southwestern Nat. 13, 401-410.

Studier E. H. \& Procter J. W. (1971) Respiratory gases in burrows of Spermophilus tridecemlineatus. F. Mammal. 52, 631-633.

SzegváRI Gy. \& VÁRNAI I. (1962) The effect of hypercapnia on heat production and colonic, muscle, and subcutaneous temperature in the rat. The site of thermoregulatory heat production. Acta physiol. Acad. Sci. Hung. 22, 65-72.

Szegvári Gy., VÁrnai I. \& Donhoffer Sz. (1963) The effect of environmental temperature, hypoxia and hypercapnia on total heat production and on the electrical activity of muscle in the rat. Shivering and non-shivering thermogenesis and the site of non-shivering heat production. Acta physiol. Acad. Sci. Hung. 23, 49-62.

Volkert W. \& Musacchia X. J. (1970) Blood gases in hamsters during hypothermia by exposure to $\mathrm{He}-\mathrm{O}_{2}$ mixture and cold. Am. F. Physiol. 219, 919-922.

Key Word Index-Hibernation; $\mathrm{CO}_{2} ; \mathrm{O}_{2} ;$ Citellus parryi ablusus; Marmota broweri; artificial dens; nest box temperatures. 